
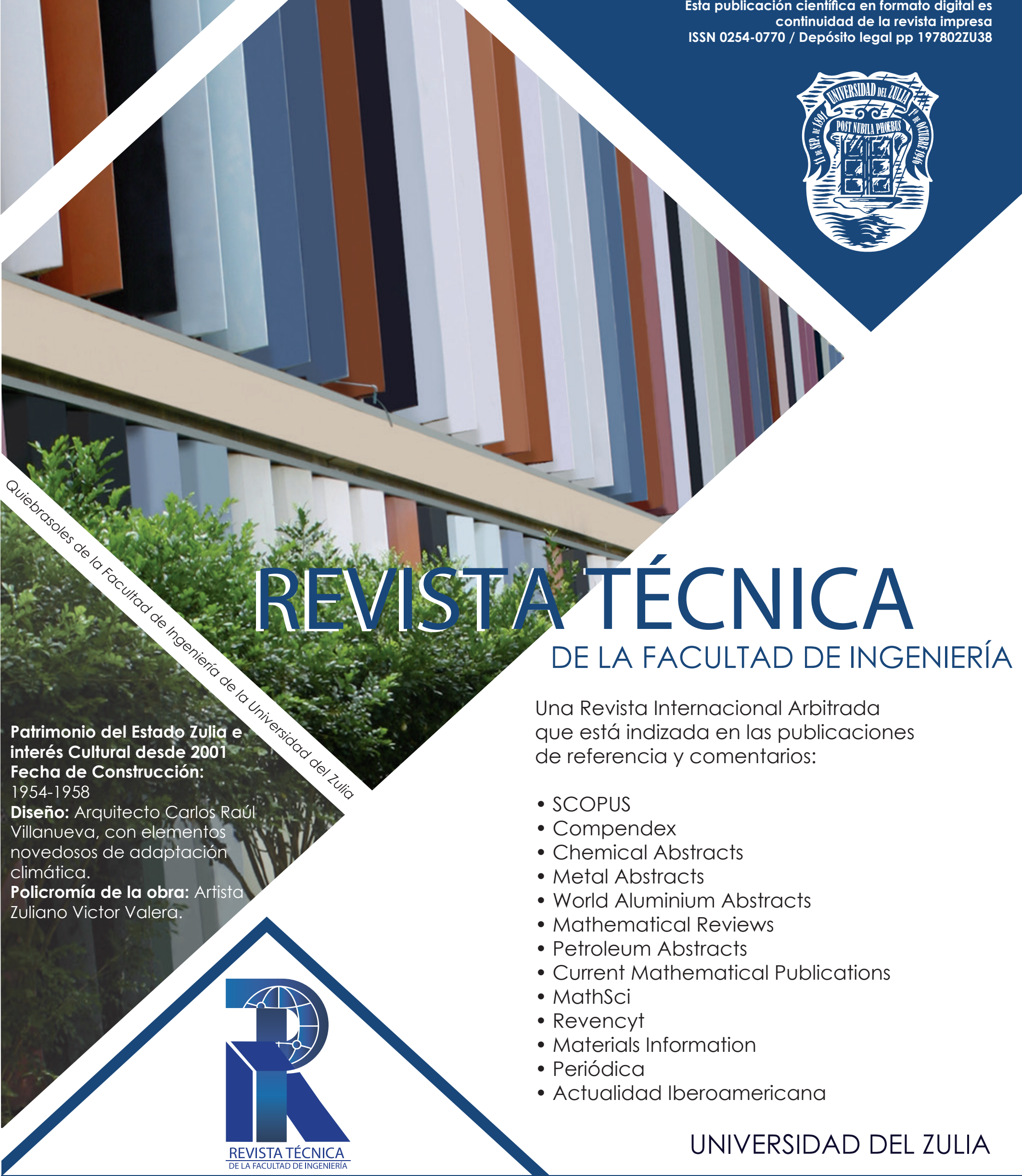
Rev. Téc. Ing. Univ. Zulia. Vol. 42, No. 3, 2019, 112-117

\title{
Study of compressive strength in artisanal adobe stabilized with cow manure, nopal sap, straw and bull blood
}

\author{
M. Ureña ${ }^{1 *} \mathbb{D}$, S. Llumitasig ${ }^{1} \mathbb{D}$, A. Siza $^{1} \mathbb{D}$, D. Coello-Fiallos $^{1} \mathbb{D}$ \\ ${ }^{1}$ Universidad Técnica de Ambato, Facultad de Ingeniería Civil y Mecánica. Avenida los Chasquis y Río Payamino, C. P. \\ 180207. Ambato, Ecuador. \\ https://doi.org/10.22209/rt.v42n3a02 \\ *Autor de Contacto: me.urena@uta.edu.ec \\ Recepción: 17/01/2019 | Aceptación: 06/05/2019 | Publicación: 01/09/2019
}

\begin{abstract}
Adobe has been used in construction since the first civilizations in the world, and to improve its mechanical properties, organic stabilizers were added. We studied the compressive strength of adobe cubic samples made with soil from the Sierra Region of Ecuador and organic stabilizers. Four organic stabilizers were studied: cow manure, nopal sap, straw and bull blood, which were added in specific percentages individually and in combination. Field and laboratory tests were carried out according to "Proyecto de actualización - versión 1 de la Norma Peruana E.080 de Noviembre 2013". The results showed that the four organic stabilizers improve the compressive strength, having an increase from 0.5 to $13.1 \%$. By using $10 \%$ of cow manure with $20 \%$ of bull blood the adobe compressive strength increased $13.1 \%$ in relation to the basic adobe.
\end{abstract}

Keywords: Compressive strength; Adobe; Organic stabilizers.

\section{Estudio de la resistencia a la compresión de adobe artesanal utilizando estabilizadores orgánicos: estiércol de vaca, savia de nopal, paja y sangre de toro}

\begin{abstract}
Resumen
El adobe ha sido usado en la construcción desde las primeras civilizaciones del mundo, para mejorar sus propiedades mecánicas, se adiciona estabilizadores orgánicos. Estudiamos la resistencia a compresión de muestras cúbicas de adobe, elaboradas a base de suelo de la Sierra ecuatoriana y estabilizadores orgánicos. Se estudiaron 4 estabilizadores: estiércol vacuno, savia de nopal, paja y sangre de toro, mismos que fueron añadidos en porcentajes específicos de forma individual y combinada. Los ensayos de campo y laboratorio se realizaron según el "Proyecto de actualización - versión 1 de la Norma Peruana E.080 de Noviembre 2013". Los resultados muestran que los cuatros estabilizadores orgánicos mejoran la resistencia a la compresión, teniendo un incremento del 0.5 a $13.1 \%$. Al usar $10 \%$ de estiércol vacuno con $20 \%$ de sangre de toro la resistencia a la compresión del adobe incrementó 13.1\% en relación al adobe básico.
\end{abstract}

Palabras clave: Resistencia a la compresión; Adobe; Estabilizadores orgánicos. 


\section{Introduction}

Earth is one the oldest and most common building material in the world, The Wall of Jericho in Palestine, of which there are still remains, it is known as the first evidence of construction with adobe since 9.000 years B.C [1]. Over the years, some structures of great religious importance, especially in the dome shape and traditional houses, have been built with earth [2]. In addition, adobe has been used in the construction of shelters for thousands of years, and approximately $30 \%$ of the current population in the world still live in structures built with this material $[2,3]$. This is due the earth is a construction material respectful of the environment, abundantly available and with basic construction technology [4-7]. Currently, a rich cultural heritage of earth construction can be found in Africa, Iran, Afghanistan, Yemen, Iraq, Syria, Spain, Germany, England, France, Portugal, Italy, Denmark and Sweden [2]. In India, according to the 1971 Census, $73 \%$ of all buildings are made of earth. In Perú, $60 \%$ of the houses are built with adobe or tapial. In general, this type of construction has been used mainly by the rural population of low economic resources [8].

The basic adobe brick is made of a mixture of earth and water, this is put in molds and left drying in the open air, even direct to the sun [4]. This material has excellent thermal and acoustic properties $[8,9]$, but it can also present some disadvantages such as its moderately low compressive strength, low tensile strength, and low water resistance. To overcome these problems, certain additives called stabilizers must be added, these components improve the basic adobe properties such as compressive strength, tensile strength, abrasion resistance, density, porosity, impermeability and hardness [4].

Common additives are divided into three categories: mineral, synthetic and organic. Two sources of organic materials are known; a vegetable source such as straw, palm leaves, rice husks, and nopal sap; and an animal source such as hair, excrement and animal blood $[4,10]$. On the other hand, sand is considered like an excellent mineral stabilizer that reduces shrinkage and swelling of the soil used to make mud, improving its properties [4]. The amount of sand and clay is very important for the adobe elaboration process if there is not enough of clay, the mixture does not achieve the necessary cohesion to support the actions of external agents, and hence adobe blocks can fall apart. On the contrary, if there is not an adequate amount of sand, cracking occurs due to shrinkage of the clay during the drying process [11].

The amount and type of stabilizer used in several researchs depends of the characteristicis of soil. Several reasearches report that cow manure is a stabilizer that provides cohesion and plasticity to the soil, reducing the expansion and contraction, providing strength and hardness. In India, traditionally this organic stabilizer is mixed with water and five portions of soil by weight and applied to fill surface cracks [4]. Straw which is a vegetable fiber provides tensile strength, reduces cracking, decreases density and accelerates drying $[4,6,7,12,13]$, the nopal sap provides durability against external agents $[4,14]$, as well as hardness and improve the compression strength, waterproofing and density. Furthermore, animal blood mixed with soil attributes, as animal manure, provides hardness and water resistance [4]. In 2012, the British architect Jack Munro used animal blood to make bricks as an innovative project, due to the water scarcity in rural areas of Egypt. So, he proposed to replace water with animal blood, because it was a widely wasted substance in ancient times and he used it as a natural glue and agglutinating to solidify the soil, creating a new waterproof construction material of high cohesion $[4,15]$. Some organic stabilizers are widely available and can be obtained at low cost or not cover.

In this study, the adobe compressive strength of cubic samples adding organic stabilizers were analyzed. We use cow manure, nopal sap, straw and bull blood, which were added individually and in combination (up to 3 stabilizers at a time) in certain percentages in relation to total weigth, obtaining 10 total combination.

\section{Materials and Methods}

The materials used in this study were soil extracted from Latacunga-Ecuador, drinking water (for the mud mixture) and 4 organic stabilizers (o.s). The solid o.s were straw (s) and cow manure $(\mathrm{cm})$, the liquid o.s were bull blood (bb) and nopal sap (ns). The o.s used in this study were prepared previously, according to the literature [4,14,15-18]. The nopal was cut into small pieces and it was immersed in water for 5 days to obtain the main substance. Equal weight proportions of nopal and water were used, the cow manure was left to stand for 4 days. On the other hand, the straw was dried, and it was cut into pieces of $5 \mathrm{~cm}$ in length, and finally, the bull blood used was fresh and it was treated with anticoagulant (DAFLON 500mg), and a preservative - antibacterial (Mentilparabeno). The anticoagulant was added in amount of $10 \%$ by weight of blood and the Mentilparabeno was added in the amount of $5 \mathrm{~g} /$ liter of blood [15].

The standar used for this work was "El proyecto de actualización - versión 1 de la Norma Peruana E.080" "Construcción con tierra" de noviembre 2013 [19] because the "Norma Ecuatoriana de la Construcción 2015" (NEC $2015)$, references it to establish requirements, technical design and construction criteria for earth buildings [20]. In the same context, another standard that regulates earth structures is ASTM E2392 / E2392M - 10 (2016), it is a Standard Guide for Design of Earthen Wall Building Systems; it contains some similar topics to E.080.

The first process to make the adobe cubes was to 
verify the adequate amount of clay in the soil, carrying out two field tests called "Cinta de Barro" y "Resistencia Seca", as established the Peruvian standard [19]. According to the Unified Soil Classification System (USCS), the soil had $71 \%$ of material passing the No. 200 sieve (particle sizes $>=0.075 \mathrm{~mm}$ ) and $29 \%$ of material retained the No. 200 sieve (particle sizes $<0.075 \mathrm{~mm}$ ). The liquid limit was $26.3 \%$, plastic limit $33.1 \%$ and the plasticity index was $6.8 \%$. Therefore, the classification of the soil is CL-ML (silty clay with sand).

So "the mud" (fresh mixture of clay, sand and water) was elaborated according to E.080 and left to stand under shade for 48 hours, acquiring the denomination of "resting mud" (RM) [16]. After, half part of water was mixed for every five parts of RM to obtain the called "activated mud" (AM) [16], it was cured at room temperature for 30 days, taking the name of basic adobe (BA), after this process we can perfomed the destructive test.

The o.s were incorporated in a specific type of mud to make the adobe cubes. In AM sample were adding only solid o.s, while in RM both liquid and solid o.s were added individually and combinated. Table 1 shows the percentages used for dosing (by weight) of the organic stabilizers used. For convenience of identification we assigned a code por each combination.

Table 1. Percentages by weight of the organic stabilizers added to elaborate the cubic samples

\begin{tabular}{|c|c|c|c|c|c|c|}
\hline \multirow{2}{*}{$\begin{array}{c}\text { TYPE OF } \\
\text { MUD }\end{array}$} & \multicolumn{4}{|c|}{ ORGANIC STABILIZERS (\%) } & \multirow{2}{*}{ CODE } & \multirow{2}{*}{$\#(*)$} \\
\hline & bb & ns & cm & $\mathbf{s}$ & & \\
\hline \multirow{3}{*}{$\mathrm{AM}$} & - & - & - & - & BA & 1 \\
\hline & - & - & - & 3 & A-1s & 2 \\
\hline & - & - & 10 & - & $\mathrm{A}-2 \mathrm{~cm}$ & 3 \\
\hline \multirow{7}{*}{$\mathrm{RM}$} & 20 & - & - & - & $\mathrm{R}-1 \mathrm{bb}$ & 4 \\
\hline & 20 & - & - & 3 & $R-2 b b$ & 5 \\
\hline & 20 & - & 10 & - & $\mathrm{R}-3 \mathrm{bb}$ & 6 \\
\hline & - & 28 & - & - & $\mathrm{R}-1 \mathrm{~ns}$ & 7 \\
\hline & - & 28 & - & 3 & $\mathrm{R}-2 \mathrm{~ns}$ & 8 \\
\hline & - & 28 & 10 & - & R-3ns & 9 \\
\hline & - & 28 & 10 & 3 & $\mathrm{R}-4 \mathrm{~ns}$ & 10 \\
\hline
\end{tabular}

Six adobe test samples were prepared for each type of combination (total 60), but only the four best compressive strength were considered as established by the Peruvian standards. The samples had a cubedshaped of $0.10 \mathrm{~m}$ of edge [19]. For the destructive test, a CONTROLS concrete compression machine was used, it has a maximum load capacity of $2000 \mathrm{KN}$ and a maximum calibration tolerance of 200KN (Figure 1).
In Figure 2, we present photographs of the different mixtures proposed for this study. The photograph 1 shows activated mud without stabilizers, photographs 2 and 3 show activated mud with straw and cow manure respectively. Photographs 4 to 10 show the mixtures of resting mud with the different stabilizers in the proportions stablished in the Table 1.

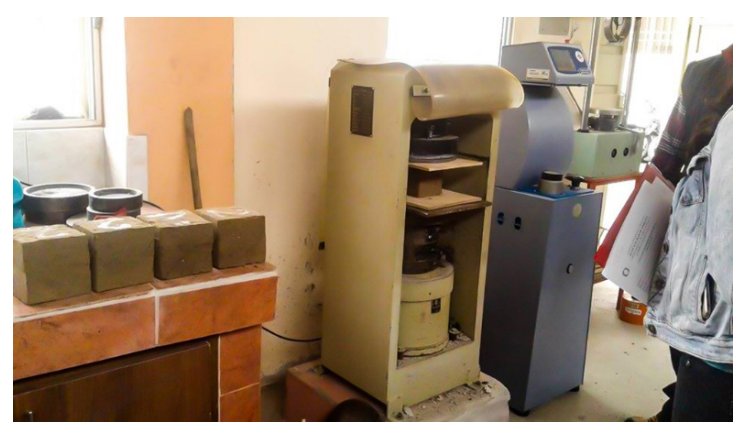

Figure 1. Standardized adobe samples for the test in the compression machine.
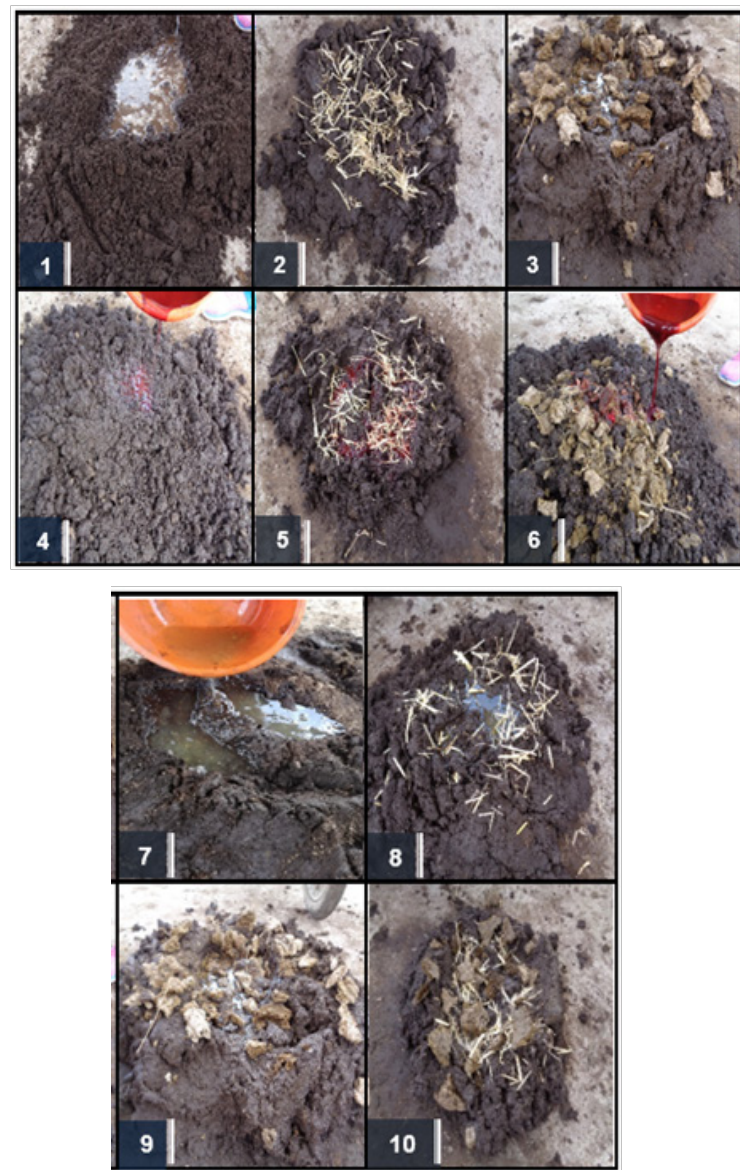

Figure 2. Mixtures with the different organic stabilizers 


\section{Results and Discussion}

Figure 3 shows the average compressive strength and the standard deviations of the adobes made from combinations proposed. The standard deviations are very small, the minimum and the maximum standard deviation value are 0.005 and $0.022 \mathrm{MPa}$ respectively, it means that the data are closely distributed (instead of widely spread) around the mean value, indicating accuracy in the preparation of the samples in each combination, as well as a close monitoring of the compression test.

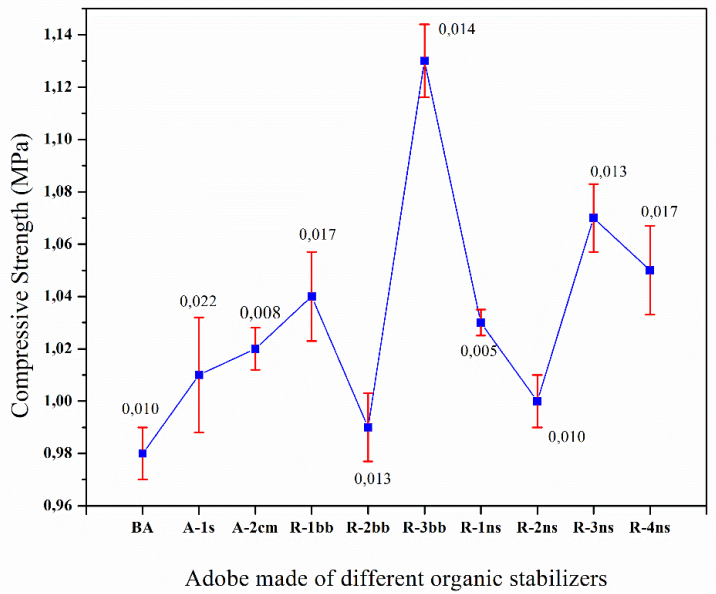

Figure 3. Standard deviation of adobe compressive strength values for each combination.

In this study we obtained a compressive strength of $0.98 \mathrm{MPa}$ in the $\mathrm{BA}$, this value is $2 \%$ less than the one specified by the Peruvian standard (1 MPa), may be due to the fact that we used as a reference as a standard that does not correspond to the country where the clay was extracted. Therefore, we can take that value only as a reference.

However, is evident that the addition of the different stabilizers proposed increases the compressive strength of the BA and in many cases exceeds the resistance established in this standard. Table 2 shows the 4 highest values of compressive strength of the 10 proposed combinations, their average and rate of increase in each case.

The common solid organic stabilizer in R-3bb, R-3ns and R-4ns combinations was cow manure, obtaining the highest values of compressive strength:1.13 $\mathrm{MPa}, 1.07 \mathrm{MPa}$ and $1.05 \mathrm{MPa}$ respectively, it means to a rate of increase of $13.1 \%, 8.0 \%$ and $6.2 \%$ respectively in relation to the BA (see Figure 4). The combination R-3bb reached the greater compressive strength (1.13MPa), it is equivalente to a compressive force of $11300 \mathrm{~N}$, while the (BA) reached a compressive strength of $0.98 \mathrm{MPa}$ being equivalente to a compressive force of $9800 \mathrm{~N}$. So, R-3bb resists $1500 \mathrm{~N}$ additional compared to the tradicional adobe BA.
Table 2. Data of the compression test of the adobe cubes made of different stabilizers and muds

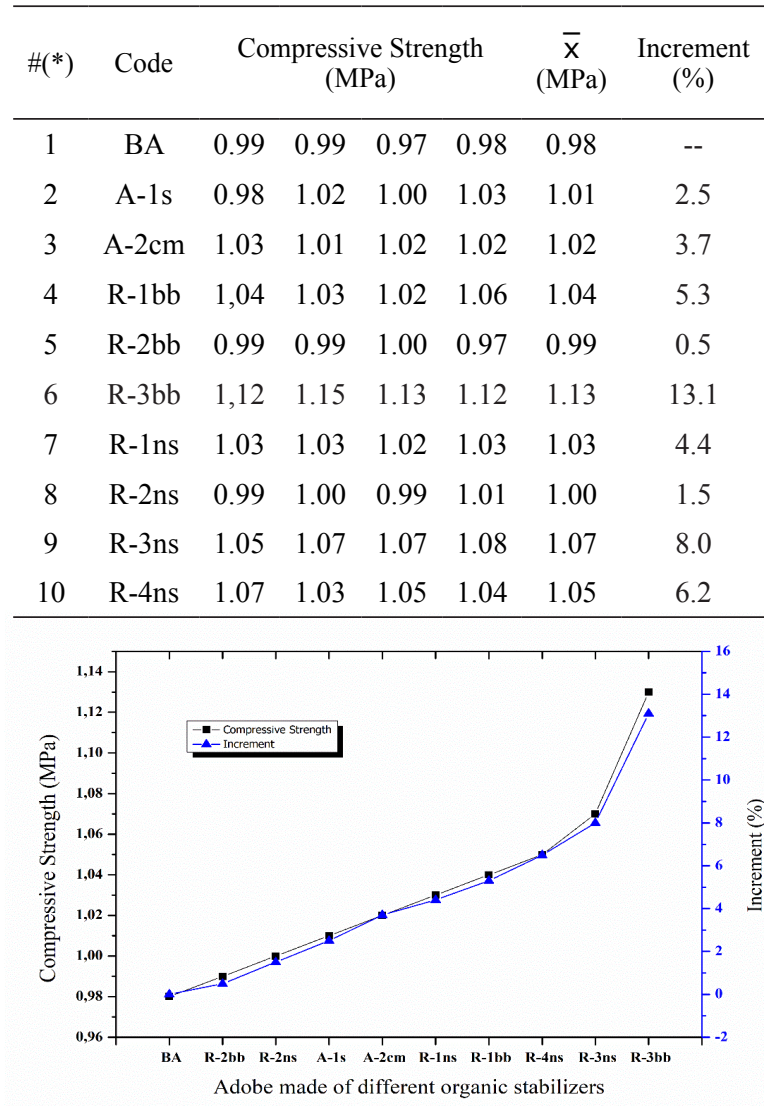

Figure 4. Graph in increasing order of the compressive strength and its rate of increase in relation to the basic adobe by each type of adobe.

The mixture of bull blood and the cow manure adding to the resting mud (R-3bb) to make adobe had the highest average compressive strength $(1.13 \mathrm{MPa})$. This could be due to the bull blood when is incorporated and compacted with the soil is able to form a material of great hardness and cohesion making it sustainable and safe for residential construction, this criteria is also reported by J. Munro [15]. The cow manure contributed to the adobe compressive strength because it contains fibrous material, phosphoric acid and potassium improving the material behavior $[4,18]$.

The adobe cubes that contains straw A-1s, R-2bb and R-2ns with the exception of the R-4ns, achieved a lower rate of increase in compressive strength, $0.5 \%, 1.5 \%$ and $2.5 \%$ respectively, this performance is mainly due to the plant fiber only increase the tensile strength $[4,6,7,12]$. Previous studies have shown that the fibers decrease the compressive strength because when they are wet are susceptible to rotting, affecting its durability $[4,13]$. 
The mixture of nopal sap with cow manure (R-3ns) in the adobe exceeds the compressive strength of $\mathrm{BA}$ by $8.0 \%$, reaching the second highest strength $(1.07 \mathrm{MPa})$ in this study, this is because when the sap is mixed with the RM gives a good compressive strength.

\section{Conclusions}

In this study we used four organic stabilizers to elaborate adobe sample and reached increase of compressive strength, the percentage increase was of $0.5 \%$ to $13.1 \%$ in relation to adobe without organic stabilizer. The combination of cow manure and bull's blood adding to make adobe present the best compression behavior, reaching the higher increase in relation to adobe without organic stabilizer.

The gather results can be considered as a precedent for future research in order to evaluate other mechanical properties of the adobe using the proposed stabilizers, due in most of the regions this is a type of construction that is clearly artisanal, where the organic stabilizers are incorporated without any technical knowledge. On the other hand, this research will also encourage to build more earth buildings due to the easy affordability of the materials and stabilizers used in this type of construction. Finally, these stabilizers are highly recommended to improve the structural behavior of buildings made of earth.

\section{References}

[1] Rodríguez M., Saroza B.: Identificación de la composición óptima del adobe como material de construcción de una escuela en Cuba. Materiales de Construcción, Vol 56, № 282 (2006) 53-62.

[2] Jokhio G, Syed S, Gul Y. et.: Statistical Analysis of Compressive and Flexural Test Results on the Sustainable Adobe Reinforced with Steel Wire Mesh. IOP Conf. Ser.: Mater. Sci. Eng. № 342 012041(2018).

[3] Coffman R, Agnew N, Austin G, Doehne E.: Adobe Mineralogy: Characterization of adobes from around the world. Clay Chemistry and Microstructure, (1990) 424-429.

[4] Bahobail M.: The mud additives and their effect on thermal conductivity of adobe bricks. Journal of Engineering Sciences, Assiut University, Vol 40, № 1 (2012) 21-34.

[5] Ren K., Kagi D.: Upgrading the durability of mud bricks by impregnation. Building and Environment, Vol 30, № 3 (1995) 433-440.

[6] Binici H., Aksogan O., Bodur M., Akca E., Kapur S.: Thermal isolation and mechanical properties of fibre reinforced mud bricks as wall materials. Construction and Building Materials, Vol 21 № 4 (2007) 901-906.

[7] Binici H., Aksogan 0., Shah T.: Investigation of fibre reinforced mud brick as a building material. Construction and Building Materials. Vol 19, № 4 (2005) 313-318.

[8] Blondet M., Villa G., Brzev S.: Construcciones de Adobe Resistentes a los terremotos: Tutor, Lima: Earthquake Engineering research Institute, 2003.

[9] Neves, C., Faria, O.: Técnicas de construcción con tierra. FEB-UNESP/PROTERRA, Bauru - Brasil 2011. http:// www.academia.edu/35702284/T\%C3\%A9cnicas_ de_construcci\%C3\%B3n_con_tierra

[10] Díaz, I.: La piel de la arquitectura de tierra sustancias naturales al servicio de la restauración de superficies del patrimonio vernáculo edificado. Las Palmas de Gran Canaria: Universidad de Las Palmas de Gran Canaria 2015.

[11] Saroza B., Rodríguez M., Menéndez J., Barroso, I.: Estudio de la resistencia a compresión básico del adobe elaborado con suelos procedentes de Crescencio Valdés, Villa Clara, Cuba. Informes de la Construcción, Vol 60, № 511, (2008) 41-47.

[12] Hanifi B., Orhan A., Derya B., Hasan K., Bilge I.: Sound insulation of fibre reinforced mud brick walls. Construct. Build. Mater., Vol 23, (2009), 1035-1041.

[13] Pacheco-Torgal F., Jalali S. (2012). Earth construction: Lessons from the past for future eco-efficient construction. Construct. Build. Mater., Vol 29, (2012), 512-519.

[14] Vargas J., Heredia E., Bariola J., Mehta P.: Proyecto Financiado por la Agencia para el Desarrollo Internacional. Preservación de las Construcciones de adobe en áreas lluviosas. http://cidbimena.desastres.hn/ docum/crid/Abril2006/CD1/pdf/spa/doc14038/ doc14038-a.pdf

[15] Munro, J. Munro Estudio. Sanguis et pulvis. https:// issuu.com/jackmunro/docs/120904 medals portfolio print small 2

[16] Blondet M., Vargas J., Torrealva D., Rubiños A.: Construcciones de Adobe Resistentes a los terremotos, Fondo Editorial de la Pontificia Universidad Católica de Perú, Lima-Perú, octubre 2010.

[17] Minke, G. Manual de Construcción en Tierra, Editorial Fin de Siglo, Alemania (2005).

[18] New Zealand Digital Library Project. Department of Computer Science, University of Waikato, New 
Zealand). Stabilizers and Mortars (for compressed earth blocks), GTZ, 1994, 20 p. http://www.nzdl.org/ gsdlmod?e $=\mathrm{d}-00000-00---$ off-0hdl--00-0----0-10-0--0---0direct-10---4-------0-11--11-en-50---20-about--00-0-1-00-0--4----0-0-11-10-0utfZz-8-00\&cl=CL1.16 $\& d=H A S H 05930481 a 9804 a 3 b a 0 d d 4 a .6 \& g t=2$.
[19] Proyecto de Actualización - Versión 1 de la Norma Peruana E.080 Construcción con tierra. Ministerio de vivienda, construcción y saneamiento MVCS, 2013.

[20] NEC-SE-VIVIENDA. Viviendas de hasta 2 pisos con luces de hasta $5 \mathrm{~m}$. Ministerio de Desarrollo Urbano y Vivienda MIDUVI, 2015. 


\section{REVISTA TECNICA}

DE LA FACULTAD DE INGENIERIA

UNIVERSIDAD DEL ZULIA

Vol. 42. N³, Septiembre - Diciembre 2019, pp. 104 -151

Esta revista fue editada en formato digital y publicada en Septiembre de 2019, por el Fondo Editorial Serbiluz, Universidad del Zulia. Maracaibo-Venezuela

www.luz.edu.ve

www.serbi.luz.edu.ve

produccioncientifica.luz.edu.ve 